\title{
Histological, immunohistochemical and biochemical effects of bee bread on stomach tissue of obese rats
}

\author{
Doganyigit $Z^{1}$, Yakan $B^{2}$, Soylu $\mathrm{M}^{3}$, Kaymak E${ }^{1}$, Okan A ${ }^{1}$, Silici $\mathrm{S}^{4}$ \\ Yozgat Bozok University, Faculty of Medicine, Department of Histology and Embryology, \\ Yozgat, Turkey.zuleyha.doganyigit@gmail.com
}

\begin{abstract}
Obesity is a major health problem threatening humanity in medical, social and psychological dimensions. In this study, we aimed to determine the histological, immunohistochemical and biochemical effects of bee bread, added to diets of obese rats in different doses, on leptin and ghrelin expression. In the study, 40 female Sprague-Dawley $(200-250 \mathrm{~g})$ rats were randomly divided into 5 equal groups and then assigned to control and obesity groups. The obesity group consisted of four subgroups: high-fat diet group, 100 and 200 $\mathrm{mg} / \mathrm{kg} / \mathrm{bw}$ groups, and metformin group. Histopathological evaluation revealed structural deterioration and necrotic areas in the epithelium and glands of the obese rats' stomach tissue, while in their serum and gastric tissues, the MDA level was significantly higher than in the other groups. There was a negative correlation between leptin and ghrelin levels. Apoptotic cells increased with obesity, but the application of beebread was similarly effective as metformin administration in reducing this increase (Tab. 5, Fig. 4, Ref. 51). Text in PDF www.elis.sk

KEY WORDS: bee bread, leptin, ghrelin, stomach, obesity, rat.
\end{abstract}

\section{Practical applications}

Obesity is one of the most important health problems of the modern age. Many of the methods developed to treat this health problem are related to dietary substances. At this point, bee products are becoming increasingly important as a natural and healthy diet option.

In the present study, histological, immunohistochemical and biochemical effects of bee bread feeding on leptin and ghrelin expression in obese rats were evaluated. As a functional food with rich nutrients and antioxidant activity, bee bread, has the potential to be a support product in the cure of obesity.

\section{Introduction}

Although the prevalence of obesity differs in various countries in recent years, the studies on obesity prevention have gained im-

${ }^{1}$ Yozgat Bozok University, Faculty of Medicine, Department of Histology and Embryology, Yozgat, Turkey, ${ }^{2}$ Erciyes University, Faculty of Medicine, Department of Histology and Embryology, Kayseri, Turkey, ${ }^{3}$ Biruni University, Faculty of Health Sciences, Nutrition and Dietetic Department, Istanbul, Turkey, ${ }^{4}$ Erciyes University, Seyrani Faculty of Agriculture, Department of Medical Biotechnology, Kayseri, Turkey, and ${ }^{4}$ Natural Therapy Company, Erciyes Technopark, Kayseri, Turkey

Address for correspondence: Z. Doğanyiğit, PhD, Yozgat Bozok University Faculty of Medicine Department of Histology- Embryology, Yozgat, Turkey.

Phone: +90.03542126201 , Fax: +90.0 .3544375285$

Acknowledgement: This study was supported by Bozok University, with the project code of 6600-TF/18-166. portance nowadays, because its prevalence is increasing all over the world thus causing a significant economic loss. The most important risk factors of obesity are physical activity, age, gender, habits, education level, number of births and genetic factors (1). Many hormones in the protein structure are responsible for controlling the body weight. They act either directly or via the hypothalamus. In recent years, the research on hormones affecting the weight gain or weight loss, such as leptin and ghrelin, attracts interest (2). Leptin and ghrelin are among the fasting/satiety hormones that regulate body weight by affecting total caloric intake through fasting/satiety mechanisms (3) Ghrelin/leptin concentrations are controlled by "feedback" mechanisms through the "Y" neurons in the hypothalamus, and the body weight is kept under control in this way (4). The long-term high-fat diet (HFD) has been shown to cause obesity $(5,6)$. Bee bread, is a fermented form of pollen collected by the honey bee and stored in the honeycomb (7). Bee bread consists of protein (around $20 \%$ ), lipids (3\%), carbohydrates (24-35\%), and vitamins and minerals (3\%). It contains all essential amino acids that the human body cannot biosynthesize, proteins $\mathrm{C}, \mathrm{B}$, B2, E, H and P, sucrose, vitamins, pigments, hormones, enzymes, carotenoids and flavonoids (8). The transformation of pollen into bee bread and biochemical changes are a result of microbial activity formed mainly by lactic acid fermentation, which is caused by bacteria and yeasts. Bee bread contains a higher amount of reduced sugar, vitamin $\mathrm{K}$ and digestive enzymes of microorganisms compared to pollen of the same plant (9). The fatty acid content (10) and antibacterial (11) and antioxidant (12) properties of bee bread have been proved by scientific studies.

Obesity can cause complications such as hypertension, diabetes and dyslipidemia. Therefore, it should be treated (13). Life- 
Tab. 1. Weight changes in animals after feeding with high-fat diet.

\begin{tabular}{lccccc}
\hline Groups & G1 & G2 & G3 & G4 & G5 \\
\hline Weight Change $\%$ & $14.01 \pm 3.27^{\mathrm{a}}$ & $31 \pm 9.63^{\mathrm{b}}$ & $33.25 \pm 7.34^{\mathrm{b}}$ & $27.65 \pm 2.26^{\mathrm{b}}$ & $32.10 \pm 6.79^{\mathrm{b}}$ \\
\hline${ }^{\mathrm{a}-\mathrm{b}}$ Values with different symbols differ significantly. & & &
\end{tabular}

Tab. 2. Nutritional elements of bee bread.

\begin{tabular}{lc}
\hline Nutritional elements & Content \\
\hline Ash & $8.14 \mathrm{~g} / 100 \mathrm{~g}$ \\
Protein & $13.56 \mathrm{~g} / 100 \mathrm{~g} / \mathrm{N} \mathrm{x} \mathrm{6.25)}$ \\
Carbohydrate & $30.60 \mathrm{~g} / 100 \mathrm{~g}$ \\
Dietary fiber & $18.18 \mathrm{~g} / 100 \mathrm{~g}$ \\
Fat & $21.69 \mathrm{~g} / 100 \mathrm{~g}$ \\
Energy & $408 \mathrm{kcal} / 100 \mathrm{~g}$ \\
\hline
\end{tabular}

style changes such as those associated with diet and exercise are prominent in the cure of obesity. However, the traditional pharmaceutical drugs are still considered the primary treatment option. These drugs are very expensive and they lead to problems due to their severe adverse toxicities associated with their long-term use (14). Therefore, there is a need to discover safer weight management alternatives that provide superior efficacy. It is thought that the rich nutrient content and positive health effects of bee bread, which is functional food, will have an important impact on obesity. Therefore, our goal is to investigate the effects of bee bread on leptin and ghrelin expression by immunohistochemical and biochemical analyses in obese rats.

\section{Materials and methods}

\section{Experimental design}

Ethics committee approval for this study was received from Erciyes University (Protocol no: 15/67). Sprague-Dawley adult female rats obtained from Erciyes University were used in the study. The water and nutrient requirements of the rats housed in their cages were provided at $21^{\circ} \mathrm{C}$ and in a light/dark environment lasting 12 hours under normal day/night conditions. Forty female rats weighing 200-250 g were planned to be randomized into 5 equal groups, but the rats were first assigned to control (n: 8) and obesity groups (n: 32). The rats in the obesity group were fed a diet with a high commercial fat content (high-fat diet composed of fat $(31.67 \%)$, soybean oil (4\%), sucrose $(8.85 \%)$, casein $(25$ $\%$ ), maltodextrin $(16 \%)$, cellulose $(6.45 \%)$, potassium $(2.13 \%)$, calcium (2) $1.292 \%$ vitamin, $1.292 \%$ mineral and methionine \%) for 4 weeks, and their weights were measured and recorded on a weekly basis. The rats in the control group were fed with standard rat feed during this period and their weights were recorded. The rats with weight increase by $10-25 \%$ compared to the control group were evaluated as obese (15) (Tab. 1). The obese rats were grouped as follows. Two different doses of beebread (16), or metformin (17) were given orally, while other rats continued to be fed with high-fat content.

Group 1: Control group

Group 2: Obese rats fed with HFD

Group 3: Obese rats fed with beebread $(100 \mathrm{mg} / \mathrm{kg} / \mathrm{day})$

Group 4: Obese rats fed with beebread ( $200 \mathrm{mg} / \mathrm{kg} / \mathrm{day})$
Group 5: Obese rats fed with metformin (300 mg/kg/day)

Metformin is an agent that improves insulin sensitivity; also, it is well known to reduce body weight $(18,19)$. For this reason, it will be used as positive control.

Lyophilized apilarnil purchased from Nutral Therapy Company (Erciyes University Technopark, Kayseri) was used for experiments. The nutrient content of the bee bread used in the research is given in Table 2. Ash, protein, carbohydrate, dietary fiber and energy content of bee bread were determined by the AOAC official methods of analysis (20).

After completing the experimental protocol, the rats were sacrificed under ketamine and xylazine anesthesia, and blood and tissue samples were collected. Blood and tissue samples were examined by methods described below.

\section{Histological analysis}

Stomach samples were fixed with $10 \%$ formaldehyde for histological analysis. After fixation, the tissues were embedded in paraffin by applying the routine tissue follow-up steps. Then, 5 - $\mu \mathrm{m}$ sections of paraffin blocks were stained with hematoxylineosin (H \& E) and examined under Olympus BX51 microscope to see general histological structure.

\section{Immunohistochemical analysis}

To investigate the differences in leptin and ghrelin expression in stomach, immunohistochemical tissue labelling was performed using the avidin-biotin-peroxidase method as described (21). Images obtained using a DP71 digital camera under the Olympus BX51 model of light microscope were evaluated for differences in expression with Image $\mathrm{J}$ software.

\section{TUNEL assay}

Using the fluorescein in situ cell death detection apoptosis kit (Roche), the apoptotic cells were determined in the sections obtained from the subjects. The TUNEL method was performed using the avidin-biotin-peroxidase method as described (22). They were visualized at 450-500 $\mathrm{nm}$ wavelength under the Olympus BX51 fluorescence microscope. To calculate the apoptotic index, the apoptotic cells were counted with Image J software in fifteen different areas on images taken with 40X magnification from each section.

\section{Biochemical analysis}

Serum and tissue samples from rats were used for biochemical analysis. Catalase (CAT), superoxide dismutase (SOD), malondialdehyde (MDA), xanthine oxidase (XOD), ghrelin and leptin levels were measured in serum and gastric tissues. The protocol in the manufacturer's kits was followed to determine the levels of rat CAT (Sunred Bio, Cat. No: 201-11-5106), rat SOD (Sunred Bio, Cat. 

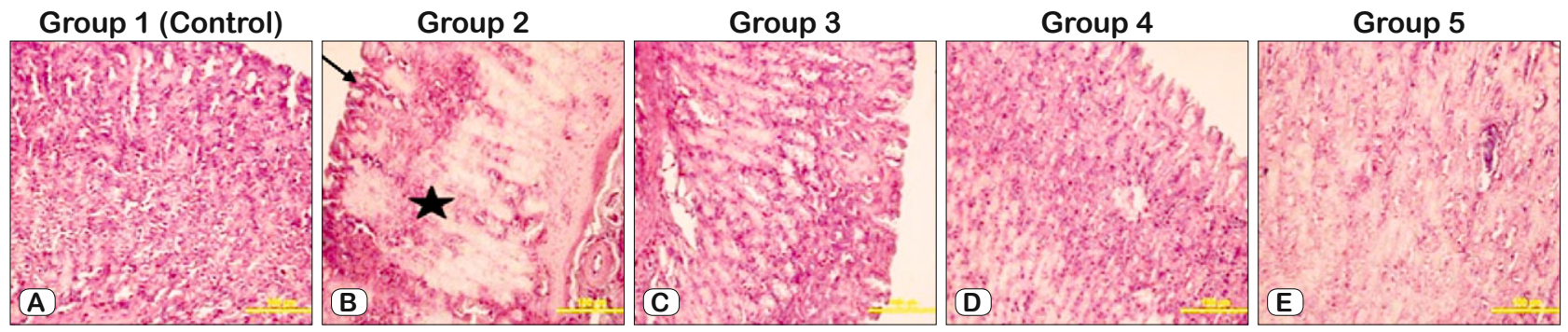

Fig. 1. Hematoxylin-eosin images of stomach tissue. Image magnification X400. Arrow shows epithelial damage. Star shows epithelial damage.
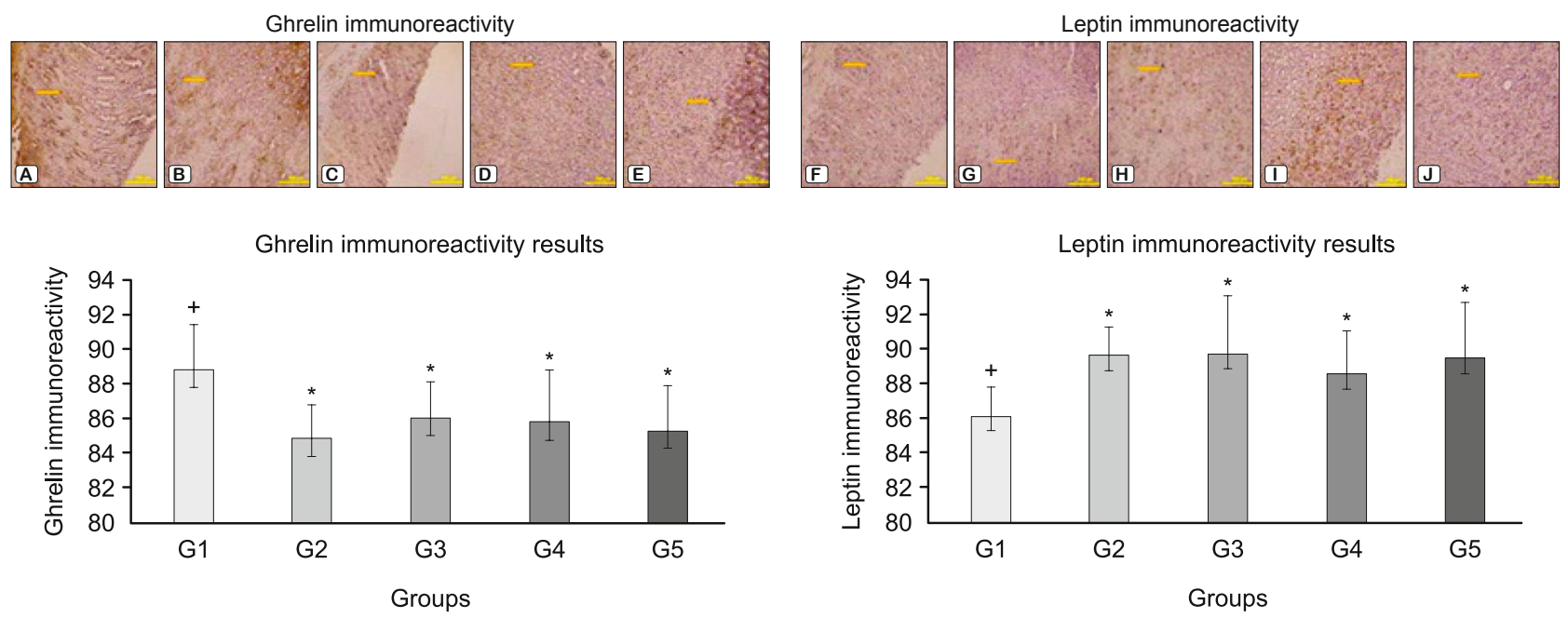

Fig. 2. Immunoreactivity values of ghrelin (A: Control, B: Group 2, C: Group 3, D: Group 4, E: Group 5) and leptin (F: Control, G: Group 2, H: Group 3, I: Group 4; J: Group 5). Immunoreactivity showed by yellow arrow.

No: 201-11-0169), rat MDA (Sunred Bio, Cat. No: 201-11-0157), rat XOD (Sunred Bio, Cat. No: 201-11-7522), rat LEP (Sunred Bio, Cat. No: 201-11-0562) and rat ghrelin (Cat. No: \#EZRGRT-91K) Optical densities were read with the ELISA reader at $450 \mathrm{~nm}$ and expressed as $\mathrm{ng} / \mathrm{ml}$ for SOD, CAT, XOD and ghrelin, $\mathrm{nmol} / \mathrm{ml}$ for MDA, and $\mathrm{pg} / \mathrm{ml}$ for LEP.

\section{Statistical analysis}

Statistical package for social science (SPSS Version 22) was used for statistical analysis. Values are expressed as mean (standard deviation). The intergroup comparison was done using oneway ANOVA test, and post hoc Tukey tests were used to carry out paired comparisons. A p value of $<0.05$ was considered statistically significant.

\section{Results}

\section{Histological analysis}

Gastric tissues from rats were examined under a light microscope with hematoxylin and eosin staining. Epithelium and mucosal glands of the control group were normal in structure. Figure 1 shows the structural deterioration of the epithelium and glands, and necrotic areas in the glands in the mucous layer of rats in the obesity group.

\section{Immunohistochemical analysis}

Figure 2 shows the immunoreactive cells of the stomach tissue staining with ghrelin and leptin, while Table 3 shows the mean and standard deviation values obtained as a result of evaluating the immunoreactivity of the fields between the groups. The immunoreactivity of ghrelin decreased significantly in Groups 2 to 5 as compared to Group1 $(\mathrm{p}<0.05)$. The immunoreactivity of leptin decreased significantly in Groups 2 to 5 as compared to the control group $(\mathrm{p}<0.05)$.

\section{TUNEL assay}

Table 4 and Figure 3 show the evaluation of apoptotic cells in the stomach tissue by means of TUNEL method. It was observed that apoptotic cells increased significantly in the obesity group compared to control and other groups. However, the highest increase in the results of TUNEL assay was seen in Group 2 (obesity group).

\section{Biochemical analysis}

Biochemical analyses of antioxidant capacity of rats showed a statistically significant increase in SOD and CAT activity in Groups 3,4 and 5 as compared to Group $2(p<0.05)$. The measurement of MDA levels for lipid damage showed a significant increase in 
Tab. 3. Immunoreactivity values of ghrelin and leptin in stomach tissue.

\begin{tabular}{lcccccc}
\hline Group & G1 (Control) & G2 & G3 & G4 & G5 & p \\
\hline Ghrelin & $88.53 \pm 2.61^{\mathrm{a}}$ & $84.92 \pm 1.92^{\mathrm{b}}$ & $86.05 \pm 2.03^{\mathrm{b}}$ & $85.84 \pm 2.94^{\mathrm{b}}$ & $85.33 \pm 2.60^{\mathrm{b}}$ & 0.001 \\
Leptin & $85.05 \pm 1.85^{\mathrm{a}}$ & $89.02 \pm 1.84^{\mathrm{b}}$ & $89.14 \pm 3.78^{\mathrm{b}}$ & $87.82 \pm 2.78^{\mathrm{b}}$ & $88.84 \pm 3.66^{\mathrm{b}}$ & 0.001 \\
\hline
\end{tabular}

Data are expressed as mean \pm standard deviation; $\mathrm{p}$ value of $<0.05$ was considered statistically significant. There was no statistically significant difference between the groups containing the same letter.

Tab. 4. Results of TUNEL assay in stomach tissue.

\begin{tabular}{lcccccc}
\hline Group & G1 (Control) & G2 & G3 & G4 & G5 & p \\
\hline TUNEL positive cell count & $0.14 \pm 0.49^{\mathrm{a}}$ & $1.02 \pm 1.05^{\mathrm{b}}$ & $0.30 \pm 0.58^{\mathrm{a}}$ & $0.20 \pm 0.57^{\mathrm{a}}$ & $0.10 \pm 0.30^{\mathrm{a}}$ & 0.001 \\
\hline
\end{tabular}

Data are expressed as mean \pm standard deviation; $\mathrm{p}$ value of $<0.05$ was considered statistically significant. There was no statistically significant difference between the groups containing the same letter.
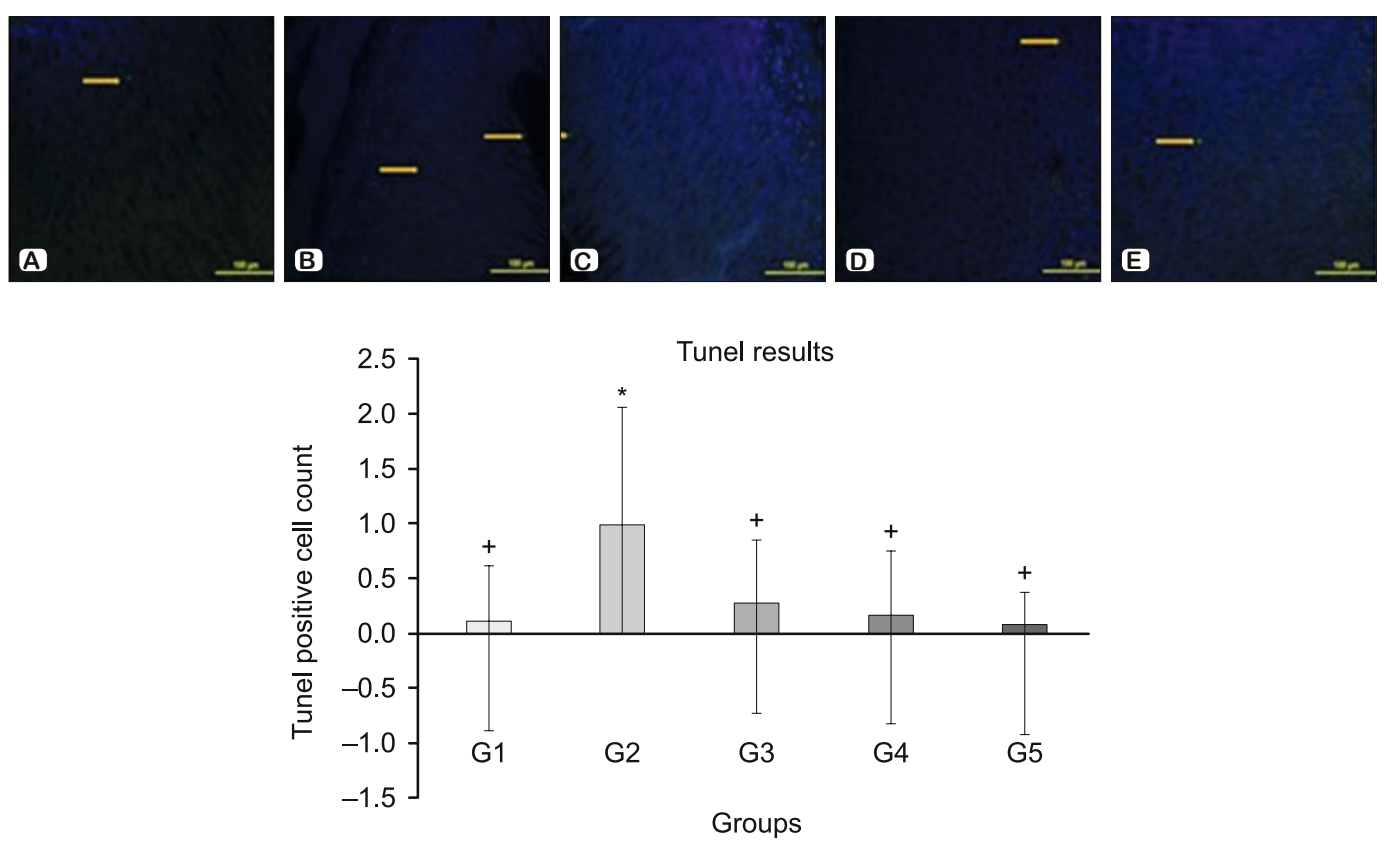

Fig. 3. TUNEL assay results (A: Control, B: Group 2, C: Group 3, D: Group 4, E: Group 5).

Group 2 as compared to the control group $(\mathrm{p}<0.05)$, but there was no significant increase when compared to the other groups. XOD levels decreased in Group 2 as compared to the other groups, but this decrease was not significant $(p>0.05)$. Ghrelin levels decreased significantly in Group 2 (obesity group) as compared to other groups. This value in Group 5 (metformin group) was found to be almost the same as that in the control group, but this decrease was suppressed in Group 4 ( $200 \mathrm{mg} / \mathrm{kg}$ bee bread). The leptin level was significantly increased in Groups 3, 4 and 5, and especially in Group 2. In Group 5 (metformin) and Group 4 (200 mg / kg bee bread) however, this increase was not statistically significant and was found to be lower than in the other groups (Tab. 5, Fig. 4).

Tab. 5. Leptin and ghrelin levels, and enzyme activities in stomach tissue.

\begin{tabular}{|c|c|c|c|c|c|c|}
\hline Group & G1 (Control) & G2 & G3 & G4 & G5 & $\mathrm{p}$ \\
\hline$\overline{\mathrm{SOD}}$ & $14.87 \pm 1.48^{\mathrm{ac}}$ & $13.50 \pm 2.59^{\mathrm{a}}$ & $18.57 \pm 0.86^{\text {bc }}$ & $21.87 \pm 2.97^{b}$ & $19.15 \pm 2.47^{\mathrm{bc}}$ & 0,001 \\
\hline CAT & $22.82 \pm 7.53^{\mathrm{a}}$ & $34.26 \pm 2.91^{\mathrm{a}}$ & $38.64 \pm 6.59^{\mathrm{b}}$ & $46.30 \pm 7.46^{\mathrm{b}}$ & $38.39 \pm 2.28^{b}$ & 0.001 \\
\hline MDA & $7.39 \pm 1.72^{\mathrm{ab}}$ & $11.30 \pm 1.23^{\mathrm{b}}$ & $8.48 \pm 2.76^{\mathrm{ab}}$ & $8.83 \pm 1.97^{\mathrm{ab}}$ & $6.73 \pm 1.42^{\mathrm{a}}$ & 0.036 \\
\hline XOD & $8.81 \pm 1.52^{\mathrm{a}}$ & $7.10 \pm 1.95^{\mathrm{a}}$ & $9.23 \pm 2.54^{\mathrm{a}}$ & $11.65 \pm 3.79^{\mathrm{a}}$ & $8.12 \pm 1.79^{a}$ & 0.162 \\
\hline Ghrelin & $30.47 \pm 2.49^{\mathrm{a}}$ & $11.98 \pm 13.06^{\mathrm{b}}$ & $15.16 \pm 9.57^{\mathrm{a}}$ & $19.17 \pm 11.74^{\mathrm{a}}$ & $30.57 \pm 1.59^{\mathrm{a}}$ & 0.029 \\
\hline Leptin & $166.04 \pm 47.89^{\mathrm{a}}$ & $283.05 \pm 44.07^{\mathrm{b}}$ & $280.97 \pm 27.73^{b}$ & $250.82 \pm 29.19^{b}$ & $248.63 \pm 7.74^{b}$ & 0.001 \\
\hline
\end{tabular}

Data are expressed as mean \pm standard deviation; $\mathrm{p}$ value of $<0.05$ was considered statistically significant. There was no statistically significant difference between the groups containing the same letter. 


\section{4-511}
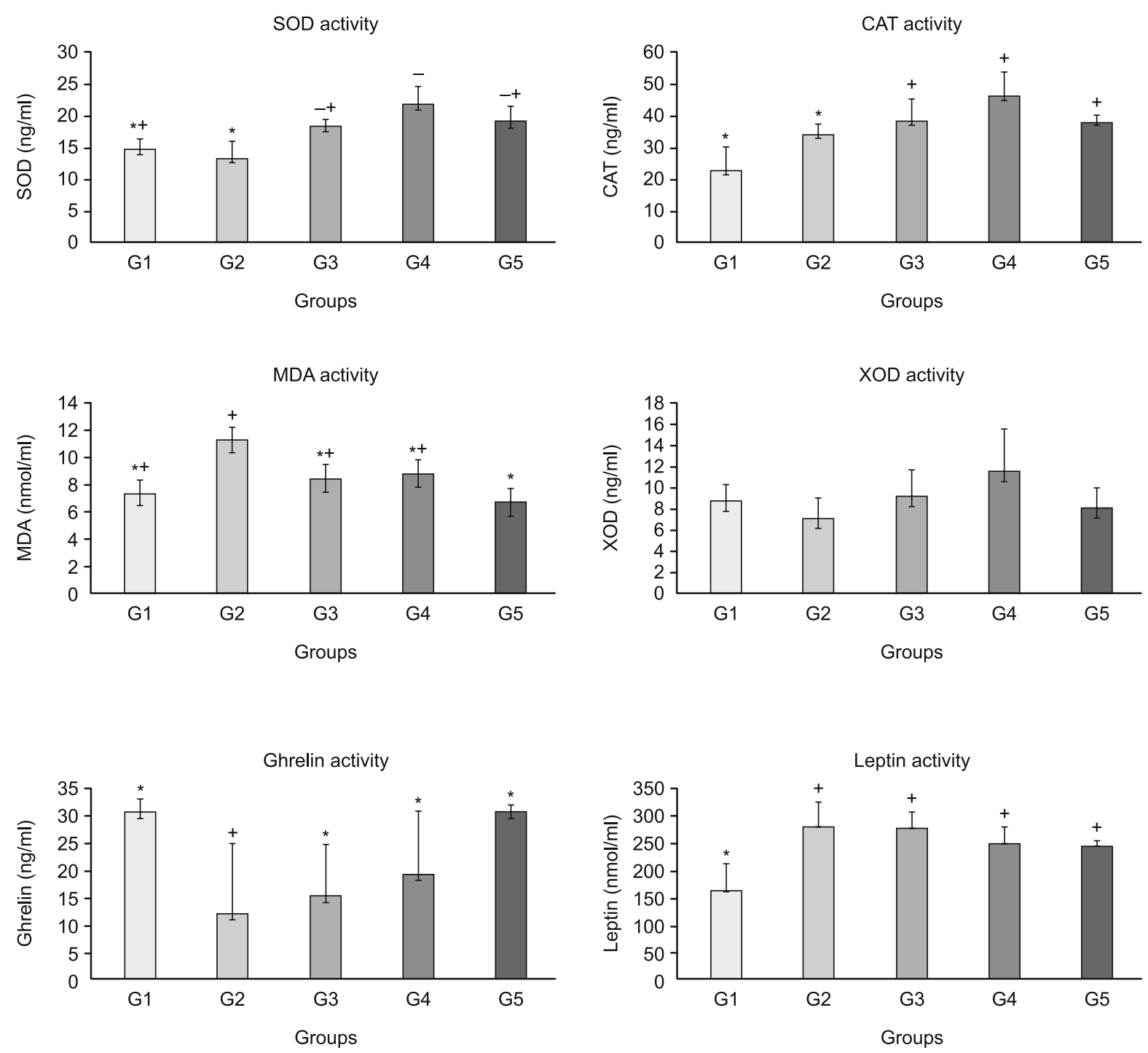

Fig. 4. Biochemical analyses. Data are expressed as mean \pm standard deviation; $p$ value of $<0.05$ was considered statistically significant. There was no statistically significant difference between the groups containing the same letter.

\section{Discussion}

The studies on the effects of natural products on obesity are increasing day by day. Among these natural products, bee products are the leading ones. There are studies on the effects of bee products on diabetes, obesity and related parameters. In one of these studies, Nna et al (23) identified anti-hyperglycemic, antioxidant, antiinflammatory and antiapoptotic activities of Malaysian propolis in streptozotocin-induced diabetic rats. In another study on propolis, evidence was demonstrated that Nigerian propolis had some hypoglycemic and hypolipidemic activities with an ability to improve organ dysfunction due to oxidative stress, as well as that it contained compounds that exhibited hypoglycemic, antihyperlipidemic and HbA1c-reducing activities. In another study on bee pollen, Mohamed et al (24) have aimed to evaluate the effects of the suspensions of bee pollen (BP) and/or date palm pollen (DPP) on the glycemic status, testicular dysfunction, oxidative stress and antioxidant defense system in streptozotocin (STZ)-induced diabetic male Wistar rats. They found that STZ-induced diabetes significantly increased blood glucose levels, malondialdehyde (MDA) and testicular nitric oxide (NO) levels in parallel with impaired testicular and pancreatic histological structure and integrity. An application of BP and DPP significantly improved all parameters compared to diabetic control group.). Therefore, it has been reported that these products could have anti-hyperglycemic effects considering their effects of elevating blood insulin levels through antioxidant activity $(24,25)$. There are also studies that determine the glycemic index of honey samples with different botanical and geographic origin (26). However, there is no study on the effect of bee bread, functional food that has yet to be researched, on obesity and related parameters. 
In this study, the effect of bee bread on obesity was evaluated especially in terms of leptin and ghrelin hormones. The ghrelin hormone stimulates eating and gastric motility. Therefore, it is a hormone that is to be investigated in the fight against obesity. Studies on this subject have shown that as the body mass index increases, plasma ghrelin levels decrease (27). It has been claimed that ghrelin, one of the peptides involved in appetite center, increases appetite and causes obesity. Wren et al. (28) showed that food intake increased when intravenous ghrelin was given to healthy normal-weight adults. It is known that the levels of ghrelin, an appetite hormone, increase with hunger and decrease after meals, especially when food with high glucose and fat content is consumed (28). Tschöp et al (29) found that ghrelin levels were lower in obese adults than in healthy controls. Similarly, the increase in ghrelin levels before and after food intake was found to be lower in obese subjects compared to normal individuals, whereas active ghrelin did not cause any change in obese individuals. It has been reported that the effect of ghrelin on body weight probably occurs through insulin regulation and does not change with fat mass (30). In this study, the ghrelin levels in obesity groups decreased compared to the control group.

The ghrelin levels in $200 \mathrm{mg} / \mathrm{kg}$ bee bread and metformin groups were found to be arithmetically close to the levels of the control group, albeit not statistically significant. However, immunohistochemical and ELISA measurements of leptin levels were significantly increased as compared with the control group. The other hormone that we examined in our study, adipose tissuederived leptin, carries information about fat tissues in the brain, reduces nutrient intake and prevents excess fat accumulation. Ghrelin provides information to the brain to increase the nutrient intake and fat tissue (31). Therefore, there is a metabolic antagonism between the functions of ghrelin and leptin in the body (32). Ghrelin levels are often inversely related to adiposity (33). In the study conducted by Zhang et al (34), they developed an obese rat model induced by 4 and 8 weeks of diet during the development of type 2 diabetes and evaluated the change in neuropeptide Y levels in the hypothalamus and its correlation with leptin and ghrelin hormones. As a result of the experiment, they showed that weight gain in the 8-week diet group was lower than in the 4-week diet group, and also that, in accordance with the literature (35), plasma ghrelin concentrations decreased with increased body weight and body fat in 4-week and 8-week diet groups (35). In our study, immunohistochemical and ELISA measurements of leptin and ghrelin levels were found to be inversely correlated with each other, which is in accordance with the literature.

In this study, the evaluation of oxidative stress parameters showed that SOD and CAT enzyme activities were statistically higher in the other groups as compared to the obese group $(\mathrm{p}<$ $0.05)$. On the contrary, the MDA level increased significantly in Group 2 (obesity group) as compared to the other groups ( $\mathrm{p}<$ 0.05 ). XOD levels were also increased in Group 2 (obesity group) as compared to the other groups, but this increase was not statistically significant $(p>0.05)$. Many studies on obese patients indicate that there is an increase in oxidative stress markers in the body, and decrease in antioxidant defense enzymes, as well as that obesity consequently causes inflammation and chronic oxidative stress in the body (36).

Increased oxidative stress in obesity has also been proposed as the main cause of tissue disorders and dysfunctions (endothelial dysfunction, increased platelet aggregation, atherogenesis, etc.) in these patients (37). Sa-nguanmoo et al (38). showed a significant increase in body weight, visceral fat content, plasma total cholesterol, LDL and insulin levels, obesity frequency and insulin resistance, and also observed a significant increase in serum MDA levels, decrease in plasma adiponectin levels, and increase in TNF- $\alpha$ levels in rats fed with high-fat diet (HFV) as compared to normal-diet fed rats (NDV). Bakour et al (12). used bee bread at a dose of $500 \mathrm{mg} / \mathrm{kg}$ bw and $750 \mathrm{mg} / \mathrm{kg}$ bw in their study, when investigating the protective effect and antioxidant activity of bee bread containing pollen, honey and bee enzymes on aluminuminduced hemato and hepatorenal toxicity in rats. They showed that the administration of aluminum resulted in a significant increase in the levels of blood urea, transaminase, and c-reactive protein, as well as in the monocyte count and a significant decrease in the hemoglobin level, but these changes improved significantly with the use of bee bread. The antioxidant activity of bee bread has been shown to have a significant protective effect against aluminum-induced toxicity in rats (12). A Moroccan study has demonstrated the antimicrobial activity of bee bread against $E$. coli, Staphylococcus aureus, Bacillus cereus, and another study have proven the antioxidant activity of water and ethanol extracts of bee bread (13).

The mechanism of the action observed in this study may be related to the antioxidant activity of bee bread. There are studies showing that honey and bee products other than bee bread have an antioxidant activity $(39,12)$. Indeed, Anarkooli et al $(40)$ concluded that treatment with insulin, honey and insulin-honey combination in streptozotocin-induced diabetic rats may prevent neuronal cell death in different hippocampal regions and that the antioxidant activity of honey protected against neuronal cell death caused by free radicals and $\operatorname{ROS}(40,41)$.

In the light of published studies showing that obesity causes apoptosis $(42,43)$, we aimed to determine whether there is a relationship between obesity and apoptosis rate, namely by assessing the levels of apoptosis in the tissues by means of TUNEL method and determining whether there was an improvement after the administration of bee bread. The results were in accordance with literature in showing that the rate of apoptosis increased in obesity groups. While the rate of apoptosis in the metformin group was comparable with that of the control group, it was found that there was a decrease in the obesity-induced increase in the apoptotic ratio in both bee bread groups. The effects in the $200 \mathrm{mg} / \mathrm{kg} /$ day bee bread group were found to be comparable with those in the control and metformin (positive control) groups. Increased epidemiological results offer that metformin reduces the incidence and severity of stroke. In addition, a clinical study showed that metformin reduced oxidative stress by reducing the ROS production and improving the antioxidant reserve (44). Anti-proliferative and antiapoptotic properties of metformin have also been demonstrated in several studies (45). The neuroprotective effects of metformin 
504-511

have been confirmed in various disease models. Metformin has been reported to have a protective effect against cerebral ischemia by reducing oxidative stress (46).

Under physiological conditions, the small amount of ROS produced via aerobic mechanisms is cleared by cellular defense systems, but the increased oxidative stress can reduce or even eliminate the activity of these defense systems. Besides, the administration of antioxidants enhances the cleansing of oxidative species by inhibiting their formation and strengthening the endogenous antioxidant defense system (47). It has been shown that ROS and the resulting oxidative stress play a very important role in apoptosis, whereas antioxidants are known to inhibit or delay this process (48). A study by Li et al (42), has shown that HFD causes obesity and lipid metabolism disorder, and increases germ cell apoptosis in rats by altering the morphological structure of the testis (42). It has been shown that long-term HFD consumption leads to obesity, as well as to cognitive impairment, metabolic disorder, increased oxidative stress and cell apoptosis in the hippocampus (43). In a study, in which honey was used among the bee products, Kilicoglu et al (49) showed that honey decreases hepatic deterioration and apoptosis due to oxidative stress in an experimental jaundice model. Neamatallah et al (50), have shown that both manuka and talc honeys limit apoptotic signals in an experimental model of cisplatin-induced hepatotoxicity and nephrotoxicity in rats. Kismet et al (51) showed that propolis reduced hepatocyte apoptosis in a TUNEL test.

Today, many aspects of nutritional activity, including prevention of certain diseases and/or therapeutic purposes, are now considered by human beings. Considering the current vogue of natural life and diet, the place of bee products in this field is also of importance. As a functional food, bee bread, which is one of the bee products, has the potential to be a support product in the cure of obesity with its rich nutrients and antioxidant activity. There is a need for further studies on this subject and to clarify its mechanisms of action.

\section{References}

1. Altunkaynak BZ, Özbek E. Obezite: Nedenleri ve Tedavi Seçenekleri. Van Med J 2006; 13 (4): 138-142.

2. Alphan MET. Obezitenin etiyolojisi. İçinde: Baysal A, Baş Meditörler. Yetişkinlerde Ağırlık Yönetimi. İstanbul, İstanbul, Ekspress Printing House 2008; 17-34.

3. Cooper JA, Watras AC, Paton CM, Wegner FH, Adams AK, Schoeller DA. Impact of exercise and dietary fatty acid composition from a high-fat diet on markers of hunger and satiety. Appetite 2011; 56 (1): 171-178. https://doi.org/10.1016/j.appet.2010.10.009.

4. Aydın S. Discovery of Ghrelin Hormone: Research and Clinical Applications. Turk J Biyochem 2007; 32 (2): 76-89.

5. Pipatpiboon N, Pratchayasakul W, Chattipakorn N, Chattipakorn SC. PPAR gamma agonist improves neuronal insulin receptor function in hippocampus and brain mitochondria function in rats with insulin resistance induced by long term high-fat diets. Endocrinol 2012; 153 (1): 329-338. https://doi.org/ 10.1210/en.2011-1502.
6. Pratchayasakul W, Kerdphoo S, Petsophonsakul P, Pongchaidecha A, Chattipakorn N, Chattipakorn S.C. Effects of high-fat diet on insulin receptor function in rat hippocampus and the level of neuronal corticosterone. Life Sci 2011; 88 (13-14): 619-627. https://doi.org/ 10.1016/j. lfs.2011.02.003.

7. Vasquez A, Olofsson TC. The lactic acid bacteria involved in the production of bee pollen and beebread. J Apic Res 2009; 48: 189-195. https:// doi.org/10.3896/IBRA.1.48.3.07.

8. Haydak MH, Vivino AE. The changes in the thiamine, riboflavin, niacin and pantothenic acid content in the food of female honeybees during growth with a note on the vitamin $\mathrm{K}$ activity of royal jelly and beebread. Ann Entomol Soc Am 1950; 43: 361-367.

9. Haydak MH. Pollen substitutes-bee bread. Am Bee J 1958; 98: 145-146.

10. Kaplan M, Karaoglu Ö, Eroglu N, Silici S. Fatty Acid and Proximate Composition of Bee Bread. Food Technol Biotech 2016; 54 (4): 497-504. https://doi.org/10.17113/ftb.54.04.16.4635.

11. Abouda Z, Zerdani I, Kalalou I, Faid M, Ahami MT. The Antibacterial Activity of Moroccan Bee Bread and Bee-Pollen (Fresh and Dried) against Pathogenic Bacteria. Res. J. Microbiol 2011; 6 (4): 376-384. https:// doi.org/ 10.3923/jm.2011.376.384.

12. Bakour M, Al-Waili NS, El Menyiy N, Imtara H, Figuira AC, AlWaili T, Lyoussi B. Antioxidant activity and protective effect of bee bread (honey and pollen) in aluminum-induced anemia, elevation of inflammatory makers and hepato-renal toxicity. Food Sci Technol 2017; 54 (13): 42054212. https://doi.org/ 10.1007/s13197-017-2889-9.

13. Haslamand DW, James WPT. Obesity. The Lancet 2005; 366 (9492): 1197-209. https://doi.org/10.1016/S0140-6736 (05)67483-1.

14. Yimam M, Jiao P, Hong M, Brownell L, Lee YC, Hyun EJ et al. Appetite Suppression and Antiobesity Effect of a Botanical Composition Composed of Morus alba, Yerba mate, and Magnolia officinalis. J Obes 2016; 4670818. https://doi.org/10.1155/2016/4670818.

15. Hariri N, Thilbault $\mathbf{L}$. High-fat diet-induced obesity in animal models. Nutr Res Rev 2010; 23: 270-299. doi: 10.1017/ S0954422410000168.

16. Eraslan G, Kanbur M, Silici S, Liman CB, Altınordulu S, SoyerSarıca Z. Evaluation of protective effect of bee polen against propoxure toxicity in rat. Ecotoxicol Environ Saf 2009; 72 (3): 931-937. https://doi. org/10.1016/j.ecoenv.2008.06.008.

17. Pyra AK, Saha CD, Reimer AR. Prebiotic fiber Increases Hepatic Acetyl CoA Carboxylase phosphorylation and Suppresses Glucose- Dependent Insulinotropic Polypeptide Secretion More Effectively When Used with Metformin in Obese Rats. Nutr J 2012; 142: 213-220. https:/doi. org/10.3945/jn.111.147132.

18. Kim YW, Kim JY, Park YH, Won KC, Choi KH, Huh JY et al. Metformin Restores Leptin Sensitivity in High-Fat- Fed Obese Rats with Leptin Resistance, Diabetes 2006; 55:716-724. doi: 10.2337/diabetes.55.03.06. db05-0917

19. Malin SK, Kashyap SR. Effects of metformin on weight loss: potential mechanisms. Curr Opin Endocrinol 2014; 21: 323-329. doi: 10.1097/ MED.0000000000000095.

20. A.O.A.C. Official Methods of Analysis of AOAC International, Association Official Analytical Chemists. Rockville, 2005; USA.

21. Ozan E, Sonmez MF, Ozan S, Colakoğlu N, Yılmaz S, Kuloğlu T. Effects of melatonin and vitamin $\mathrm{C}$ on cigarette smoke-induced damage in the kidney. Toxicol Ind Health 2007; 23: 479-485. 
22. Bayatlı F, Akkuș D, Kılıc E, Saraymen R, Sonmez MF. The protective effects of grape seed extract on MDA, AOPP, apoptosis and Enos expression in testicular torsion: an experimental study. World J Urol 2013; 31: 615-622.

23. Nna VU, Bakar ABA, Mohamed M. Malaysian propolis, metfor$\mathrm{min}$ and their combination, exert hepatoprotective effect in streptozotocininduced diabetic rats. Life Sci 2018; 211: 40-50. https://doi.org/10.1016/j. lfs.2018.09.018.

24. Mohamed NA,Ahmed OM, Hozayen WG,Ahmed MA. Ameliorative effects of bee pollen and date palm pollen on the glycemic state and male sexual dysfunctions in streptozotocin-induced diabetic wistar rats. Biomed Pharmacother 2018;97:9-18.https://doi.org/10.1016/j.biopha.2017.10.117.

25. Oladayo MI. Nigerian propolis improves blood glucose, glycated hemoglobin A1c, very low-density lipoprotein, and highdensity lipoprotein levels in rat models of diabetes. J Intercult Ethnopharmacol 2016; 5 (3): 233-238.

26. Atayoğlu AT, Soylu M, Silici S, İnanç N. Glycemic index values of monofloral Turkish honeys and the effect oftheir consumption on glucose metabolism. Turk J Med Sci 2016; 17: 483-488. https://doi.org/ 10.3906/ sag-1502-102.

27. Cao Y, Tang J, Yang T, Ma H, Yi D, Gu C. Cardioprotective Effect of Ghrelin in Cardiopulmonary Bypass Involves a Reduction in Inflammatory Response. Plos One 2013; 8 (1): e55021. https://doi.org/10.1371/ journal.pone.0055021.

28. Wren AM, Seal LJ, Cohen MA, Brynes AE, Frost GS, Murphy KG et al. Ghrelin Enhances Appetite and Increases Food Intake in Humans. J Clin Endocrinol Metab 2001; 86 (12): 5992-5996. https://doi. org/10.1210/jcem.86.12.8111.

29. Tschöp M, Weyer C, Tataranni PA, Devanarayan V, Ravussin E, Heiman, MI. Circulating Ghrelin Levels are Decreased in Human Obesity. Diabetes 2001; 50 (4): 707-709. https://doi.org/10.2337/diabetes.50.4.707.

30. Iyidoğan Y. Ghrelin Yapısı ve Organizmadaki Fonksiyonları. J Istanbul Fac Med 2007; 70: 82-92.

31. Yiş U, Öztürk Y, Büyükgebiz B. Ghrelin: A new hormone in regulating energy metabolism. J Child Health Dis 2005; 48: 196-201.

32. Bilgin HM. Ghrelin; gündemdeki hormone. Dicle Med J 2006; 33 (4): $268-272$.

33. English PJ, Ghatei MA, Malik IA, Bloom SR, Wilding JP. Food fails to suppress ghrelin levels in obese humans. J Clin Endocrinol Metab 2002; 87: 2984. https://doi.org/10.1210/jcem.87.6.8738.

34. Zhang Q, Yang C, Zhang S, Zhang L, Jie L. Alteration of NPY in hypothalamus and its correlation with leptin and ghrelin during the development of T2DM in a rat model. Springer Plus 2016; 5 (1): 1913. https:// doi.org/ 10.1186/s40064-016-3555-9.

35. Briggs DI, Enriori PJ, Lemus MB, Cowley MA,Andrews ZB. Diet induced obesity causes ghrelin resistance in arcuate NPY/AgRPneurons. Endocrinology 2010; 51 (10):4745-4755. https://doi.org/10.1210/en.2010-0556.

36. Vincent HK, Taylor AG. Biomarkers and potential mechanisms of obesity-induced oxidant stress in humans. I J Obes 2006; 30:400-418. doi: 10.1038/sj.ijo.0803177.

37. Uzun H, Zengin K, Taskin M, Aydin S, Simsek G, Dariyerli N. Changes in leptin, plasminogen activator factor and oxidative stress in morbidly obese patients following open and laparoscopic Swedish adjustable gastric banding. Obesity Surg 2004; 14:659-665. https://doi.org/ 10.1381/096089204323093453.
38. Sa-nguanmoo $P$, Tanajak $P$, Kerdphoo $S$, Jaiwongkam $T$, Wang X, Liang G, Chattipakorn SC. FGF21 and DPP-4 inhibitor equally prevents cognitive decline in obese rats. Biomed Pharmacother (2018; 97: 1663-1672. https://doi.org/10.1016/j.biopha.2017.12.021.

39. Al-Waili N, Hozzein W, Badr G, Al-Ghamdi A, Al-Waili H, Salom K. Propolis and bee venom in diabetic wounds; a potential approach that warrants clinical investigation. Afr J Tradit Complement Altern Med 2015; 12 (6): 1-11. https://doi.org/ 10.4314/ajtcam.v12i6.1.

40. Anarkooli IJ, Ganji HB, Pourheidar J. The Protective Effects of Insulin and Natural Honey against Hippocampal Cell Death in Streptozotocin-Induced Diabetic Rats. Diabet Res 2014; 491571. https://doi.org/ 10.1155/2014/491571.

41. Sreemantula S, Kilari EK, Vardhan VA, Jaladi R. Influence of antioxidant (L-ascorbic acid) on tolbutamide induced hypoglycaemia/antihyperglycae miain normal and diabetic rats. BMC Endocr Disord 2005; 5:1152, 2. doi: 10.1186/1472-6823-5-2.

42. Li NC, Wei XX, Hu YL, Hou X, Xu H. Aerobic exercise blocks interleukin- 6 levels and germ cell apoptosis in obese rats. Andrologia 2018; 25: e12880. https://doi.org/10.1111/and.12880.

43. Chunchai T, Apaijai N, Keawtep P, Mantor D, Arinno A, Pratchayasakul W, Chattipakorn N, Chattipakorn SC. Testosterone deprivation intensifies cognitive decline in obese male rats via glial hyperactivity, increased oxidative stress, and apoptosis in both hippocampus and cortex. Acta Physiol (Oxf) 2018; e13229. https://doi.org/10.1111/apha.13229.

44. Esteghamati A, Eskandari D, Mirmiranpour H, Noshad S, Mousavizadeh M, Hedayati M, Nakhjavani M. Effects of metformin on markers of oxidative stress and antioxidant reserve in patients with newly diagnosed type 2 diabetes: a randomized clinical trial. Am J Clin Nut 2013;32: 179-185. https:// doi.org/10.1016/j.clnu.2012.08.006. https://doi.org/10.1093/aesa/43.3.361.

45. Jia J, Cheng J, Ni J, Zhen X. Neuropharmacological actions of metformin in stroke. Curr. Neuropharmacol 2015; 13:389-394. https://doi.or g/10.2174/1570159X13666150205143555.

46. Tao L, Li D, Liu H, Jiang F, Xu Y, Cao Y, Gao R, Chen G. Neuroprotective effects of metformin on traumatic brain injury in rats associated with NF-KB and MAPK signaling pathway. Brain Res Bull 2018; 140: 154-161. https://doi.org/10.1016/j.brainresbull.2018.04.008.

47. Reiter RJ, Tan DX, Gitto E, Sainz RM, Mayo JC, Leon J, Kilic U. Pharmacological utility of melatonin in reducing oxidative cellular and molecular damage. Pol j pharmacol 2004; 56: 159-170. PMID: 15156066.

48. Kannan K, Jain SK. Oxidative stress and apoptosis. Pathophysiology 2000; 7: 153-163. doi: https://doi.org/10.1016/S0928-4680 (00)00053-5.

49. Kilicoglu B, Gencay C, Kismet K, Kilicoglu SS, Erguder I, Erel S, Akkus MA. The ultrastructural research of liver in experimental obstructive jaundice and effect of honey. Am J Surg 2008; 195 (2): 249-56. https://doi.org/ 10.1016/j.amjsurg.2007.04.011.

50. Neamatallah T, El-Shitany NA, Abbas AT, Ali SS, Eid BG. Honey protects against cisplatin-induced hepatic and renal toxicity through inhibition of NF-KB-mediated COX-2 expression and the oxidative stress dependent BAX/Bcl-2/caspase-3 apoptotic pathway.Food Funct 2018; 9 (7): 3743-3754. https://doi.org/10.1039/c8fo00653a.

51. Kismet K, Sabuncuoglu MZ, Kilicoglu SS, Kilicoglu B, Devrim E, Erel $\mathbf{S}$ et al. Effect of propolis on oxidative stress and histomorphology of liver tissue in experimental obstructive jaundice. Eur Surg Res 2008; 41 (2): 231-237. https://doi.org/ 10.1159/000136479.

Received January 6, 2020. Accepted March 17, 2020. 